
agroforestry practices compared to row-crop agriculture. Over an agricultural watershed with two buffer cropping systems (agroforestry buffers and grass buffers) soybean crop

\title{
Evapotranspiration Differences between Agroforestry and Grass Buffer Systems
}

\author{
Bohumil M. Svoma ${ }^{1, *}$, Neil I. Fox ${ }^{1}$, Quinn Pallardy ${ }^{1}$ and Ranjith P. Udawatta ${ }^{1,2}$ \\ ${ }^{1}$ Soil, Environmental and Atmospheric Sciences, University of Missouri-Columbia, MO 65211. \\ ${ }^{2}$ The Center for Agroforestry, University of Missouri-Columbia, MO 65211 \\ *Corresponding author, E-mail: svomab@missouri.edu, Telephone: 573-882-8680
}

\begin{abstract}
Improved soil and water quality, and carbon sequestration are notable benefits of
\end{abstract} evapotranspiration was calculated from the Penman-Monteith equation using 10-min averages of meteorological measurements within crop alleys for 54 days in summer 2007 . Wind speeds were consistently lower over the agroforestry buffer portion of the watershed by an average of $0.42 \mathrm{~m}$ $\mathrm{s}^{-1}$. For calculated evapotranspiration assuming water-stressed conditions, this decrease in wind speed from the presence of agroforestry buffers was offset almost entirely by an increase in net radiation. Net radiation differences between the two systems were highest during the morning $\left(\sim 40 \mathrm{~W} \mathrm{~m}^{-2}\right)$ and were likely the result of solar radiation scattered from the agroforestry buffers. Wind speed reduction over the crop portion surrounded by agroforestry buffers varied by wind direction with daytime winds $\geq 0.6 \mathrm{~m} \mathrm{~s}^{-1}$ greater over the grass buffer portion of the crop for northerly and southerly winds (nearly perpendicular to the agroforestry buffers). Therefore, buffer orientation relative to the prevailing wind is important for reducing evapotranspiration. Changes in crop alley width would be expected to impact the portion of the crop within windsheltered zones and the portion receiving scattered radiation from trees. The sensitivity of evapotranspiration to agroforestry buffer orientation and crop alley width should be a focus of future investigations. 
Key Words: evapotranspiration, relative humidity, solar radiation, soybean, temperature, wind speed

\section{INTRODUCTION}

Carbon sequestration and improvements in soil and water quality are among the potential

37 benefits of agroforestry practices compared to row-crop agriculture (Quinkenstein et al., 2009;

38 Udawatta et al., 2011; 2012). Agroforestry and grass buffers have been found to reduce non-

39 point source pollution in runoff while improving soil properties (Seobi et al., 2005; Udawatta et

40 al., 2006; Kumar et al., 2008). Such improvements have been attributed to the addition of

41 organic matter, roots of the permanent vegetation, nutrient uptake, and water use (Kumar et al.,

42 2011; Udawatta et al., 2014; Chendev et al., 2015).

43 Changes in microclimate from the permanent vegetation in buffers may influence

44 evapotranspiration, soil water dynamics, carbon sequestration, nutrient dynamics, and soil

45 enzyme activities. Larger trees act as a barrier to wind speed, reducing crop damage (Brandle et

46 al., 2004) and influencing evapotranspiration and other energy fluxes in the adjacent areas

47 (Campi et al., 2009; Tamang et al., 2010). Reduced energy levels under buffers and adjacent

48 areas should promote less evapotranspiration and greater soil moisture storage. Increased crop

49 quality and yields have been found on the leeward side of windbreaks (Huth et al., 2002; Campi

50 et al., 2009). The potential for increased frost damage in the leeside of windbreaks has also been

51 noted (Tamang et al., 2010). The wind break effect varies by crop, windbreak type, geographic

52 location, moisture condition, and soil properties (Brandle et al., 2004). For example, in the drier

53 regions of Australia, long-term benefits of forest buffers to improve soil quality may be offset by

54 competition from the trees for soil moisture (Cleugh et al., 2002; Huth et al., 2002). Lopez-Bravo

55 et al. (2012) found reductions in coffee yields near shade trees in Costa Rica. 
Turbulence generated by windbreaks increases vertical mixing of heat and moisture

57 downwind of the break (Cleugh, 1998). Less vertical mixing would be expected in the 'quiet

58 zone,' resulting in warmer and moister daytime conditions compared to those in the 'wake zone.'

59 One would expect the 'wake zone' to experience greater evapotranspiration in response (Cleugh,

60 1998). Campi et al. (2009) show a peak in evapotranspiration 10 tree heights downwind of a

61 windbreak. The repeated linear structure of the forest buffers in alley cropping systems adds

62 complexity. For example, a greater proportion of the crop in the sheltered 'quiet zone', compared

63 to that in the turbulent 'wake zone', is to be expected for alley cropping systems compared to a

64 single extended windbreak. Exact extents of the quiet zone and wake zones are sensitive to the

65 turbulent structure of the incident wind, related to the site's upwind surface roughness, as well as

66 the porosity of the windbreak and wind direction. The radiation budget in crop alleys may also

67 be influenced by the tree buffers through emitted longwave and scattered shortwave radiation

68 (Brandle et al., 2004).

69 In this investigation, differences in microclimate and calculated evapotranspiration

70 between agroforestry and grass buffered areas of a soybean crop are examined. Although

71 dependent on the permeability of the buffer, the 'quiet zone' will generally extend downwind of

72 the windbreak for a distance equal to a number of tree height multiples $(\mathrm{H})$. In this investigation,

73 the distance between agroforestry buffer strips is approximately $10 \mathrm{H}$, therefore, we expect a

74 clear effect of agroforestry buffers on the microclimate within crop alleys.

75

76 2. MATERIALS AND METHODS

$77 \quad 2.1$ Experimental Site and Management 
The study site is a north aspect watershed located at the University of Missouri, Greenley

79 Memorial Research Center near Novelty, Missouri (40 $01^{\prime}$ N, $92^{\circ} 11^{\prime} \mathrm{W}$; Fig. 1). A corn (Zea

80 mays L.) and soybean [Glycine $\max ($ L.) Merr.] rotation, with contour planting and no-till land

81 preparation has been implemented on the watershed since 1991 (Udawatta et al., 2002). The

82 contour grass strip (CGS) buffer portion of the watershed is 3.16 ha with grass only buffers and

83 the agroforestry buffer portion (AGF) is 4.44 ha with grass and tree buffers. The buffer strips

84 (Fig. 1) are $4.5 \mathrm{~m}$ wide and spaced $36.5 \mathrm{~m}$ apart (22.8 $\mathrm{m}$ at lower slope positions). A grass and

85 legume combination was established in 1997 in the buffer strips and included brome grass

86 (Bromus spp.), birdsfoot trefoil (Lotus corniculatus L.) and redtop (Agrostis gigantea Roth). The

87 agroforestry buffers consisted of Pin oak trees (Quercus palustris Muenchh.) planted in the

88 center of the buffer strips at 3-m spacing. Average tree heights in the AGF area were $3.9 \mathrm{~m}$ in

89 2007. In both areas, grass waterways consist of Kentucky 31 fescue [Schedonorus phoenix

90 (Scop.) Holub]. Further details on watershed management and general experimental design, as

91 well as parent material, soils, and climatic data can be found elsewhere (Udawatta et al., 2002;

92 2006).

93 In 2006, corn was planted and harvested over both the AGF and CGS areas on 14 April

94 and 27 September respectively, with a mean yield of $11.06 \mathrm{Mg} \mathrm{ha}^{-1}$. In 2007, soybeans were

95 seeded on both the AGF and CGS areas at 444,600 seeds $\mathrm{ha}^{-1}$ on 8 June and harvested on

96 October 26 with a mean yield of $3.4 \mathrm{Mg} \mathrm{ha}^{-1}$ (Senaviratne et al., 2012). 


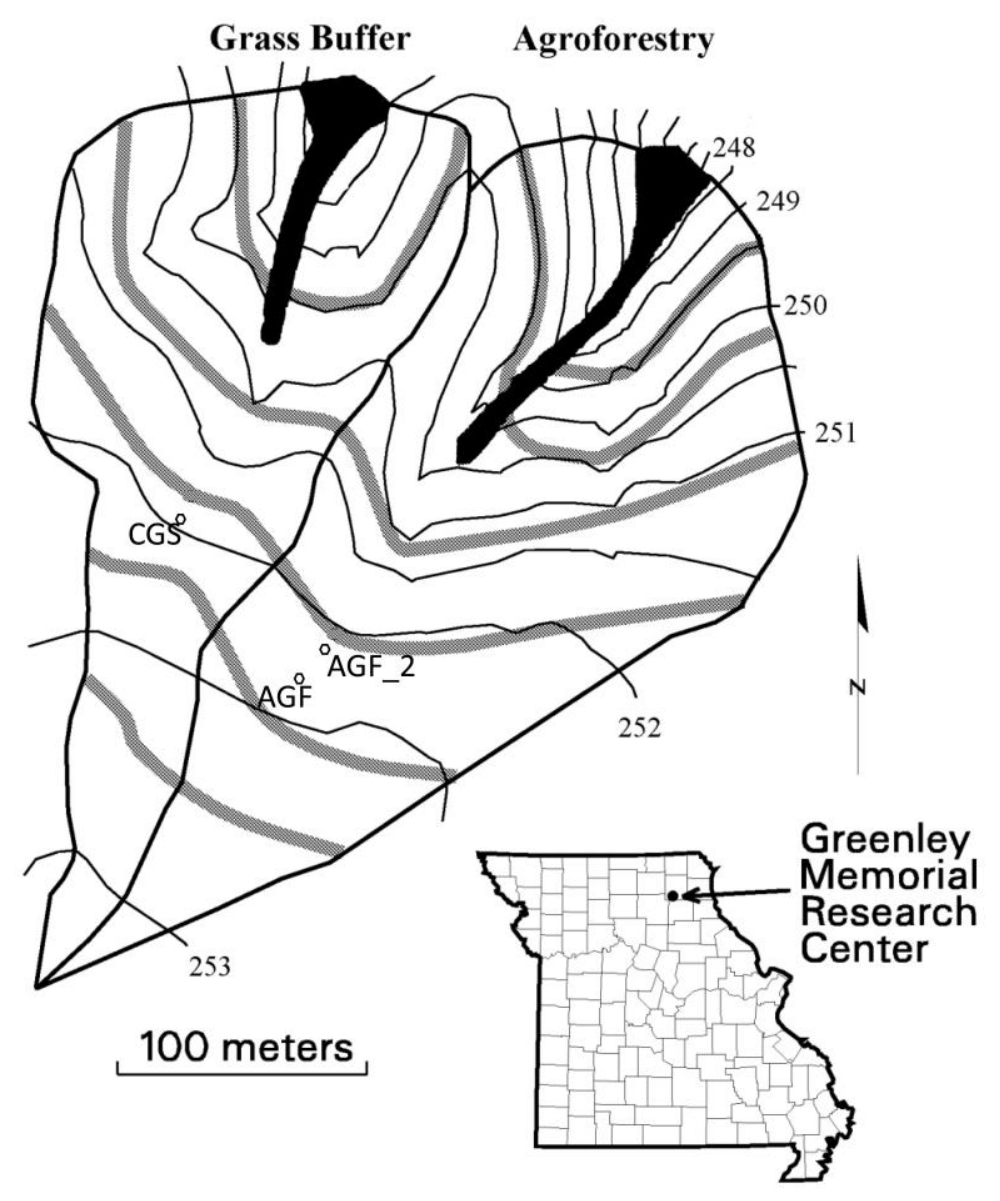

Fig. 1: Contour grass strip (grass only; CGS) buffer and agroforestry (grass and trees; AGF) buffer watersheds at the Greenley Memorial Research Center, Knox County, Missouri. Elevation contour intervals are $0.5 \mathrm{~m}$ (black). Buffers (gray), grass waterways (wide black) and microclimate station locations (circles) are also displayed.

\subsection{Microclimate Stations and Data Collection}

Net radiometers, anemometers, humidity and temperature sensors were installed on masts above the crops at $3 \mathrm{~m}$ above ground level. Data were recorded at 10 minute intervals with a CR23X data logger. The microclimate stations are $12 \mathrm{~m}$ south of the third buffers in both watersheds (Fig. 1). An additional microclimate station (AGF_2 in Fig. 1) recorded data in 2006,

108 but not 2007, on the agroforestry watershed approximately $3 \mathrm{~m}$ south from the third buffer. During the soybean year in 2007 , periods of continuous data records for all variables required for 
110 evapotranspiration calculation at both sites were 18 March - 3 May, 25 May - 15 June, 21 June -

11113 Aug, and 7 Sep - Oct 21. As soybeans were planted on 8 June 2007, the period 21 June - 13

112 August 2007 will be the focus of this investigation and this 54 day period will be referred to as

113 summer for the remainder of this paper. Crop management was identical on both the CGS and

114 AGF portions of the watershed, and soybean heights were more than $2 \mathrm{~m}$ below instrumentation

115 height through the growing season. Therefore, it is assumed that differences between treatments

116 in surface characteristics affecting net radiation, wind speed, etc. are negligible for the 54 day

117 study period.

118

\section{$119 \quad$ 2.3 Soybean Crop Evapotranspiration}

The Penman-Monteith equation was used to calculate soybean crop evapotranspiration

121 (Allen et al., 1998):

$$
E T=\frac{\Delta\left(R_{n}-G\right)+\rho_{a} c_{p} \frac{\left(e_{s}-e_{a}\right)}{r_{a}}}{L_{v}\left(\Delta+\gamma\left(1+\frac{r_{s}}{r_{a}}\right)\right)}
$$

123 where $E T$ is the crop evapotranspiration $\left(\mathrm{mm} \mathrm{s}^{-1}\right), R_{n}$ is net radiation $\left(\mathrm{W} \mathrm{m} \mathrm{m}^{-2}\right), G$ is the soil heat

124 flux $\left(\mathrm{W} \mathrm{m}{ }^{-2}\right), \Delta$ is the slope of the saturation vapor pressure curve $\left(\mathrm{kPa} /{ }^{\circ} \mathrm{C}\right), e_{s}$ is the saturation 125 vapor pressure $(\mathrm{kPa}), e_{\mathrm{a}}$ is the actual vapor pressure $(\mathrm{kPa}), \rho_{a}$ is the air density $\left(\mathrm{kg} \mathrm{m}^{-3}\right), c_{p}$ is the 126 specific heat of air at constant pressure $\left(1005 \mathrm{~J} \mathrm{~kg}^{-1} \mathrm{~K}^{-1}\right), r_{a}$ is the aerodynamic resistance $\left(\mathrm{s} \mathrm{m}^{-1}\right)$,

$127 r_{s}$ is the bulk surface resistance $\left(\mathrm{s} \mathrm{m}^{-1}\right), \gamma$ is the psychrometric constant $\left(\mathrm{kPa} /{ }^{\circ} \mathrm{C}\right)$, and $L_{v}$ is the 128 latent heat of vaporization for water $\left(2.453 \cdot 10^{6} \mathrm{~J} \mathrm{~kg}^{-1}\right)$. The aerodynamic resistance $\left(r_{a}\right)$ is given 129 by (Allen et al., 1998): 


$$
r_{a}=\frac{\ln \left[\frac{Z_{m}-d}{Z_{o m}}\right] \ln \left[\frac{Z_{h}-d}{Z_{o h}}\right]}{k^{2} u_{z}}
$$

131 where $Z_{m}$ and $Z_{h}$ are the heights $(3 \mathrm{~m}$ ) of wind and humidity measurements respectively, $d$ is the

132 zero plane displacement height $(\mathrm{m}), Z_{o m}$ and $Z_{o h}$ are the roughness lengths $(\mathrm{m})$ governing

133 momentum and heat transfer respectively, $\mathrm{k}$ is von Karman's constant $\left(0.41\right.$, unitless), and $u_{z}$ is

134 the wind speed $\left(\mathrm{m} \mathrm{s}^{-1}\right)$ at height $\mathrm{Z}_{\mathrm{m}}$. For a soybean crop, aerodynamic properties can be 135 calculated as $d=0.67 h_{c}, Z_{o m}=0.10 h_{c}, Z_{o h}=0.014 h_{c}$, where $h_{c}$ is the crop height (Ortega-Farias et 136 al., 2004). Soil heat flux $(G)$ was quantified as $0.1 R_{n}$ during the daytime hours, and $0.5 R_{n}$ during 137 the nighttime hours (Allen et al., 1998). Procedures to calculate the psychrometric constant $(\gamma)$, 138 slope of the saturation vapor pressure curve $(\Delta)$, actual vapor pressure $\left(e_{a}\right)$, and saturation vapor 139 pressure $\left(e_{s}\right)$ from the meteorological data measured in this study are given by Allen et al. (1998). Quantifying the aerodynamic properties in Equation 2 and the bulk surface resistance

141 through the growing season requires sub-seasonal measurements of crop height $\left(h_{c}\right)$, leaf area 142 index, and stomatal resistance (Allen et al., 1998; Ortega-Farias et al., 2004). Unfortunately, this 143 information is lacking from our study. Therefore, we assume constant properties of the soybean 144 crop through the growing season to isolate the effects of meteorological differences on 145 evapotranspiration from a fully developed soybean crop canopy. Ortega-Farias et al. (2004) 146 report that for a soybean crop with 55 plants $\mathrm{m}^{-2}$, a fully developed canopy has an average $h_{c}$ of $1470.65 \mathrm{~m}$ with a leaf area index of nearly $4 \mathrm{~m}^{2} \mathrm{~m}^{-2}$. Using the Penman-Monteith model and 148 excluding times of day with low solar irradiance, Baldocchi et al. (1987) calculated bulk surface 149 resistance $\left(r_{s}\right)$ for a soybean crop with a leaf area index of 3.8 in Mead, Nebraska USA for 150 conditions ranging from well-watered to water-stressed (Kelliher et al., 1995; Baldocchi et al. 151 1985; 1987). From figure 7 in Baldocchi et al. (1987), it appears that $r_{s} \sim 40 \mathrm{~s} \mathrm{~m}^{-1}$ broadly 
152 represents bulk surface resistance during well-watered periods, and $r_{s} \sim 100 \mathrm{~s} \mathrm{~m}^{-1}$ during periods

153 with some water stress. We calculate evapotranspiration from Equations 1 and 2 with $h_{c}=0.65$

$154 \mathrm{~m}$ assuming well-watered conditions $\left(E T_{W W}, r_{s}=40 \mathrm{~s} \mathrm{~m}^{-1}\right)$ and water-stressed conditions $\left(E T_{W S}, r_{s}\right.$

$\left.155=100 \mathrm{~s} \mathrm{~m}^{-1}\right)$.

\section{RESULTS}

During summer 2007, the mean daily (0000 to 2350 Local Standard Time [LST]) wind

159 speed over the contour grass strip buffer portion of the crop (CGS) was $1.94 \mathrm{~m} \mathrm{~s}^{-1}$, and $1.52 \mathrm{~m} \mathrm{~s}^{-1}$

160 over the agroforestry buffer (AGF) portion of the crop (Table 1). Using a two-sided paired $t$ test

161 on the daily averages, this $0.42 \mathrm{~m} \mathrm{~s}^{-1}$ difference was statistically significant $(p<0.05)$. Other

162 significant differences in daily average values were observed for air temperature $\left(0.18{ }^{\circ} \mathrm{C}\right.$ hotter

163 at CGS) and net radiation, with the $\mathrm{AGF}$ crop receiving on average $4.17 \mathrm{~W} \mathrm{~m}^{-2}$ more radiation

164 than the CGS crop (Table 1). Differences in calculated evapotranspiration vary from well-

165 watered $\left(E T_{W W}\right)$ to water-stressed conditions $\left(E T_{W S}\right)$, with $8.1 \mathrm{~mm}$ more $E T_{W W}$ over the CGS crop

166 than the AGF crop, and negligible differences for $E T_{W S}$ (Table 1).

Table 1: Daily averages of meteorological variables, and total calculated evapotranspiration, from the 54 day period in 2007 (21 June-13 August) for the agroforestry buffer portion of the crop (AGF) and the contour grass strip buffer portion of the crop (CGS). Asterisks (*) indicate that AGF to CGS differences are significant with $95 \%$ confidence.

\begin{tabular}{|c|c|c|c|c|c|c|}
\hline & $u_{z}\left(\mathrm{~m} \mathrm{~s}^{-1}\right)^{*}$ & $T\left({ }^{\circ} \mathrm{C}\right)^{*}$ & $R H(\%)$ & $R_{n}\left(\mathrm{~W} \mathrm{~m}^{-2}\right)^{*}$ & $E T_{w w}(\mathrm{~mm})^{*}$ & $E T_{\text {ws }}(\mathrm{mm})$ \\
\hline AGF & 1.52 & 24.46 & 74.87 & 161.91 & 278.74 & 229.81 \\
\hline CGS & 1.94 & 24.64 & 74.85 & 157.74 & 286.84 & 230.22 \\
\hline
\end{tabular}

174 displayed in Table 2. Southerly winds were most common, with 489 ten-minute averages

175 displaying a wind direction between $157.5^{\circ}$ and $202.5^{\circ}$ over the 54 day period (Table 2). Daytime 
176 southwesterly winds $\left(202.5^{\circ}\right.$ to $\left.247.5^{\circ}\right)$ were least common, recorded only 141 times over the 54

177 day period.

178 The CGS crop displayed higher winds speeds than the AGF crop for all directions,

179 significant with $95 \%$ confidence for all but southwesterly winds (Table 2). Here, statistical

180 significance is determined with a two-sided paired $t$ test on daily averages of 10-minute values

181 between 1000 and 1600 LST. The largest wind speed differences $\left(\geq 0.8 \mathrm{~m} \mathrm{~s}^{-1}\right)$ correspond to

182 north $\left(337.5^{\circ}\right.$ to $\left.22.5^{\circ}\right)$ and northwesterly $\left(292.5^{\circ}\right.$ to $\left.337.5^{\circ}\right)$ winds (Table 2$)$. Other large

183 differences are seen for southerly and southeasterly winds. The buffers are generally oriented

184 east-west (Fig. 1), so it is not surprising that winds with strong northerly or southerly

185 components display the largest differences in wind speed between the two locations (Brandle et

186 al., 2004).

187

Table 2: Daytime (1000-1600 LST) averages of the 10-minute values (totals for calculated

188

189

190

191

192

193 evapotranspiration) for the AGF location and the difference between the AGF and CGS locations $(D I F F=\mathrm{AGF}-\mathrm{CGS})$ for eight wind direction categories. For each wind direction, $\mathrm{n}$ refers to the number of 10-minute periods over the 54 day period (21 June-13 August 2007 ) with average wind direction within $22.5^{\circ}$ of the given direction. Asterisks (*) indicate that differences are significant with $95 \%$ confidence.

\begin{tabular}{|c|c|c|c|c|c|c|c|c|c|c|c|c|}
\hline & \multicolumn{2}{|c|}{$u_{z}\left(\mathrm{~m} \mathrm{~s}^{-1}\right)$} & \multicolumn{2}{|c|}{$T\left({ }^{\circ} \mathrm{C}\right)$} & \multicolumn{2}{|c|}{$R H(\%)$} & \multicolumn{2}{|c|}{$R_{n}\left(\mathrm{~W} \mathrm{~m}^{-2}\right)$} & \multicolumn{2}{|c|}{$E T_{w w}(\mathrm{~mm})$} & \multicolumn{2}{|c|}{$E T_{w s}(\mathrm{~mm})$} \\
\hline & AGF & DIFF & AGF & DIFF & AGF & DIFF & AGF & DIFF & AGF & DIFF & AGF & DIFF \\
\hline $\begin{array}{c}N\left(0^{\circ}\right) \\
(n=199)\end{array}$ & 1.53 & $-0.90 *$ & 26.65 & $0.28^{*}$ & 63.66 & -0.86 & 371.04 & 1.83 & 13.7 & -0.5 & 11.9 & 0.3 \\
\hline $\begin{array}{l}\text { NE }\left(45^{\circ}\right) \\
(n=197)\end{array}$ & 2.56 & $-0.29 *$ & 25.32 & 0.15 & 58.14 & $-0.94^{*}$ & 465.23 & 4.33 & 17.2 & 0.0 & 13.8 & 0.2 \\
\hline $\begin{array}{c}E\left(90^{\circ}\right) \\
(n=279)\end{array}$ & 2.16 & $-0.25^{*}$ & 27.99 & $-0.10 *$ & 53.78 & -0.50 & 498.36 & -5.07 & 26.7 & -0.6 & 22.3 & -0.1 \\
\hline $\begin{array}{l}\text { SE }\left(135^{\circ}\right) \\
(n=338)\end{array}$ & 2.36 & $-0.65 *$ & 29.84 & 0.03 & 55.91 & $-1.02^{*}$ & 488.59 & -6.84 & 33.2 & $-1.2^{*}$ & 27.6 & 0.1 \\
\hline $\begin{array}{l}S\left(180^{\circ}\right) \\
(n=489)\end{array}$ & 3.09 & $-0.50 *$ & 30.98 & -0.06 & 54.70 & $-0.78^{*}$ & 482.97 & -6.26 & 51.4 & $-1.6 *$ & 41.1 & -0.2 \\
\hline $\begin{array}{c}\text { SW }\left(225^{\circ}\right) \\
(n=141)\end{array}$ & 2.14 & -0.06 & 28.95 & -0.05 & 58.28 & -0.95 & 458.04 & 5.66 & 12.7 & 0.2 & 10.6 & 0.2 \\
\hline $\begin{array}{l}W\left(270^{\circ}\right) \\
(n=195)\end{array}$ & 2.29 & $-0.27 *$ & 27.98 & 0.06 & 60.44 & -0.58 & 430.82 & $10.17 *$ & 16.3 & 0.2 & 13.5 & $0.4^{*}$ \\
\hline $\begin{array}{c}N W\left(315^{\circ}\right) \\
(n=160)\end{array}$ & 1.82 & $-0.80 *$ & 29.09 & $0.20 *$ & 58.69 & -1.01 & 463.18 & 11.05 & 14.3 & -0.2 & 12.2 & 0.4 \\
\hline
\end{tabular}


While the average temperature through the summer period was warmer at the CGS site

196 (Table 1), the largest daytime temperature differences corresponded to hotter conditions at the

197 AGF crop $\left(\geq 0.20^{\circ} \mathrm{C}\right)$ and were coincident with the large wind differences of the northerly winds

198 (Table 2). Daytime relative humidity was consistently lower at the AGF crop (Table 2), even for

199 wind directions corresponding to roughly the same temperature between the sites (e.g.,

200 southeasterly). Other investigators have noted warmer and less humid daytime conditions in

201 sheltered areas adjacent to wind breaks (Campi et al., 2009).

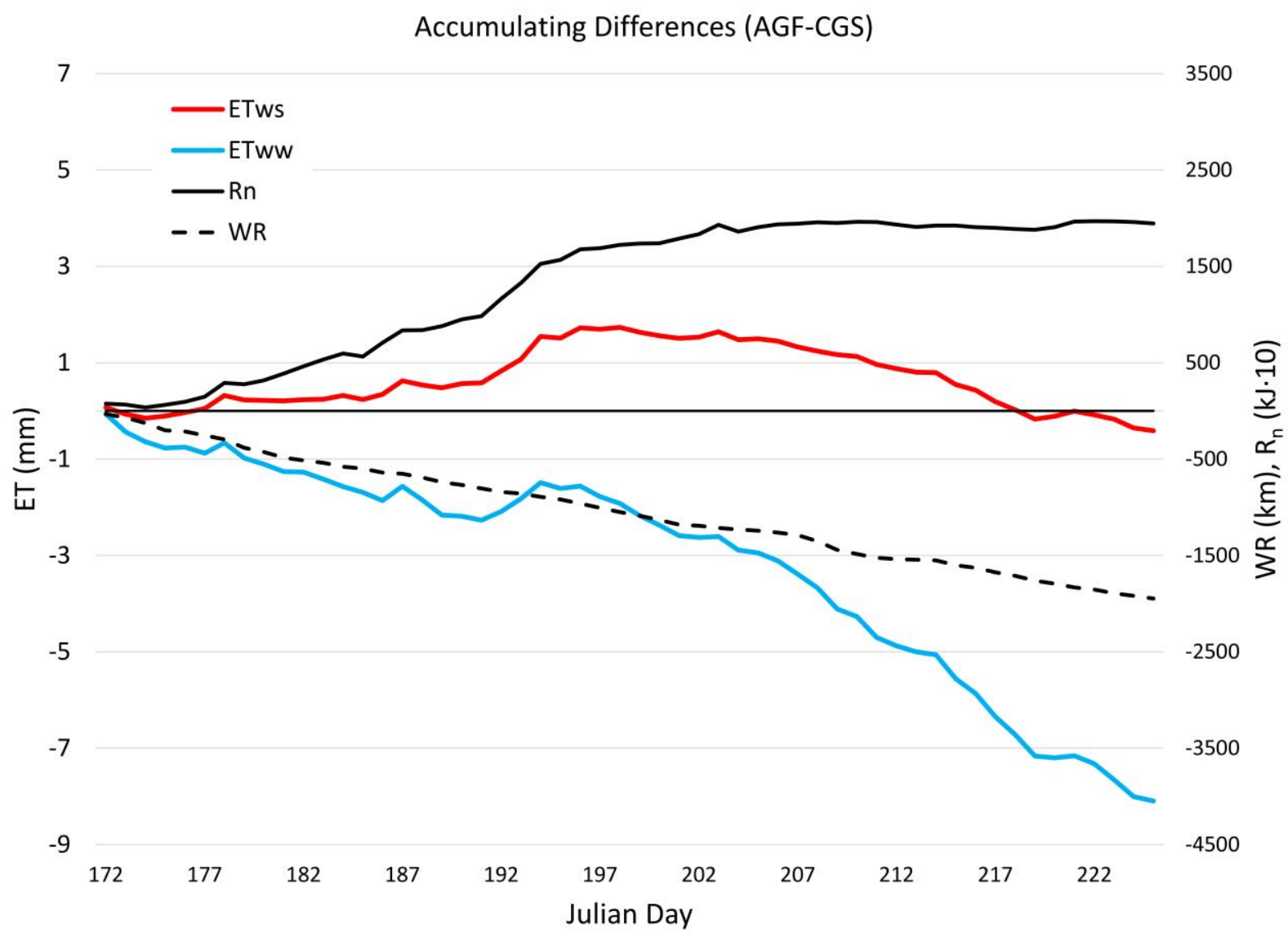

202

203

204

205

206

207

Fig. 2: Accumulating differences between the agroforestry buffer portion of the crop (AGF) and the contour grass strip buffer portion of the crop (CGS), see Fig. 1, in 2007 for calculated soybean crop evapotranspiration (red and blue lines), net radiation (black solid line), and wind run (dashed black line). 
Despite the consistently higher wind speeds at CGS, $E T_{W S}$ was only significantly lower at

209 AGF when average daytime net radiation was lower at AGF (Table 2). Daytime net radiation

210 was higher at AGF for all wind directions except easterly to southerly (Table 2). For westerly

211 winds, wind speeds are significantly higher at CGS, yet both net radiation and $E T_{W S}$ are

212 significantly higher at AGF. Therefore, there is evidence (Tables 1 and 2) that the greater net

213 radiation at AGF overcomes the impacts of the reduced wind speed, especially for

214 evapotranspiration assuming water-stressed conditions $\left(r_{s}=100 \mathrm{~s} \mathrm{~m}^{-1}\right.$ in Equation 1).

215 Through the entire summer, wind speeds were greater at CGS, as seen by the

216 accumulating differences in wind run (Acock and Pachepsky, 2000), the product of speed and

217 time, at the two sites (Fig. 2). Net radiation, however, was consistently higher at the AGF site

218 until around 23 July (Julian day 204), whereafter it remained nearly equal at the two sites.

219 Between 21 June (Julian day 172) and 15 July (Julian day 196), total $E T_{W S}$ at the AGF crop

220 location exceeded the CGS location by more than $1.7 \mathrm{~mm}$, with $\sim 16,767 \mathrm{~kJ} \mathrm{~m}^{-2}$ more net

221 radiation (Fig. 2). After $15 \mathrm{July,} E T_{W S}$ at the CGS site was greater, with the lesser net radiation

222 differences not overcoming the wind speed differences (Fig. 2). The primary difference between

223 the summer evolution of $E T_{W S}$ and $E T_{W W}$ is that the higher net radiation at the AGF site before 15

224 July site almost balances the higher wind speeds at the CGS throughout the summer for $E T_{W S}$,

225 while the wind speed differences overcome the radiation differences for nearly the entire summer

226 for $E T_{W W}$ (Fig. 2). The denominator of Equation 1 decreases evapotranspiration with increasing

227 wind speed and the impact of this component increases with increasing $r_{s}$. 


\section{DISCUSSION}

Calculated $E T_{W S}$ for summer 2007 was nearly equal between the agroforestry (AGF) and

233 contour grass strip (CGS) buffer portions of the crop despite the higher wind speeds over the

234 CGS buffer portion. This is likely due to higher net radiation at the agroforestry portion (AGF)

235 of the crop (Table 1 and Fig. 2). Brandle et al. (2004) note that emitted longwave and scattered

236 shortwave radiation from trees may increase net radiation in crop alleys compared to open areas.

237 Fig. 3 displays the daily cycle of the net radiation difference between the two locations, averaged

238 over Julian days 172-193 (21 June to 12 July). Statistical significance for all differences (i.e., all

239 10-minute periods) were determined with 144 paired $t$ tests, each with a sample size of 22

240 corresponding to the number of days between 21 June to 12 July. The AGF site experienced

241 about 13,289 $\mathrm{kJ} \mathrm{m}^{-2}$ (an average of $6.99 \mathrm{~W} \mathrm{~m}^{-2}$ ) more net radiation than the CGS site during this 242 period. 


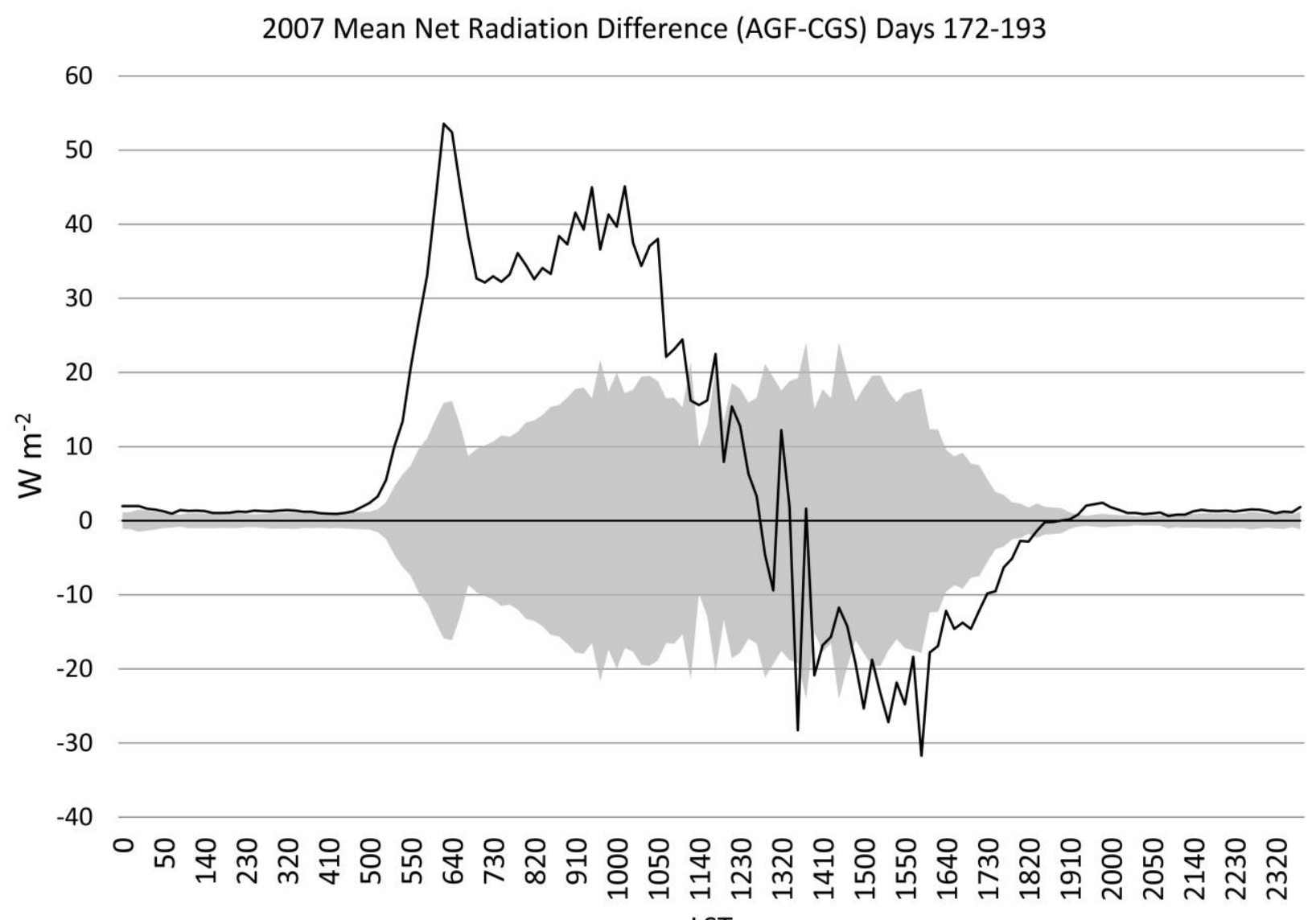

244

Fig. 3: The mean net radiation difference (black line) between the agroforestry buffer portion of the crop (AGF) and the contour grass strip buffer portion of the crop (CGS), see Fig. 1, for each 10-minute interval during Julian days 172-193 2007. The gray shading represents the $95 \%$ confidence interval centered on zero $\mathrm{W} \mathrm{m}^{-2}$ as determined by paired $t$ tests (

On Julian day 183, sunrise and sunset were approximately 0445 and 1940 LST respectively. Thus, large and statistically significant differences in net radiation between the two sites were only evident during the daytime hours (Fig. 3). This suggests that the shortwave radiation budget is more important to net radiation differences than the longwave radiation budget. Higher net radiation at the AGF site was restricted to the morning and early afternoon hours (Fig. 3). From 620-1020 LST, net radiation at the AGF site was about $40 \mathrm{~W} \mathrm{~m}^{-2}$ greater than the CGS site (Fig. 3). After 1300 LST, the CGS site displayed more net radiation, with 
258 about $20 \mathrm{~W} \mathrm{~m}^{-2}$ greater flux between 1400-1620 LST. After $1620 \mathrm{LST}$, the difference between

259 the two sites began to disappear as the sun set (Fig. 3).

260 Assuming simple isotropic scattering of incoming shortwave solar radiation from a linear

261 barrier of trees of average albedo of the order of 0.2 , then the ratio of direct to diffuse solar

262 radiation at a distance of about $10 \mathrm{~m}$ from the barrier that extends $3 \mathrm{~m}$ above the height of the

263 instruments is of the order of 0.05. This is in agreement with the models of Kuusk et al. (2014),

264 for example and suggests that for $500 \mathrm{~W} \mathrm{~m}^{-2}$ of insolation an additional $25 \mathrm{~W} \mathrm{~m}^{-2}$ will impact the

265 instruments. However, as leaves which comprise the majority of the scattering surface will not

266 scatter isotropically this is likely an overestimate, but it can be seen that it is possible that

267 scattered radiation from both AGF buffers can account for the additional net radiation.

268 With buffers oriented east-west (Fig. 1), morning radiation (solar azimuth angle due east)

269 is scattered nearly equally off both north and south agroforestry buffers surrounding the crop. As

270 the solar azimuth angle transitions to the south, one would expect scattered radiation from the

271 south buffer to decrease, especially for lower solar altitude angles. However, the solar altitude

272 angle at solar noon on Julian day 183 was $\sim 73.0^{\circ}$, which may explain why the minimum of AGF-

273 CGS did not occur until around 1500 LST (Fig. 3), when the solar altitude angle was lower

$274\left(<51^{\circ}\right)$ and the solar azimuth angle was $\sim 257^{\circ}$, approximately perpendicular to the southeast-

275 northwest oriented agroforestry buffers (Fig. 1). At this time, one would expect the south buffer

276 strip to be intercepting diffuse radiation from the sky and not contributing scattered radiation

277 from the trees to the instruments.

278 Fig. 2 suggests that the higher net radiation at the AGF site was not apparent in the later

279 part of the summer period. While the increased morning net radiation over the AGF site was

280 evident over the period 23 July - 13 August (Fig. 4), it was not apparent at solar noon as it was 
281 earlier in the summer. This may be due to the lower solar altitude angle at noon (e.g., $\sim 67^{\circ}$ on

282 August 3), resulting in little scattering off the south buffer. Without higher net radiation over the 283 AGF crop sustained beyond solar noon, the lower radiation in the afternoon hours offset the 284 increased radiation in the morning hours in August (Fig. 2 and Fig. 4).

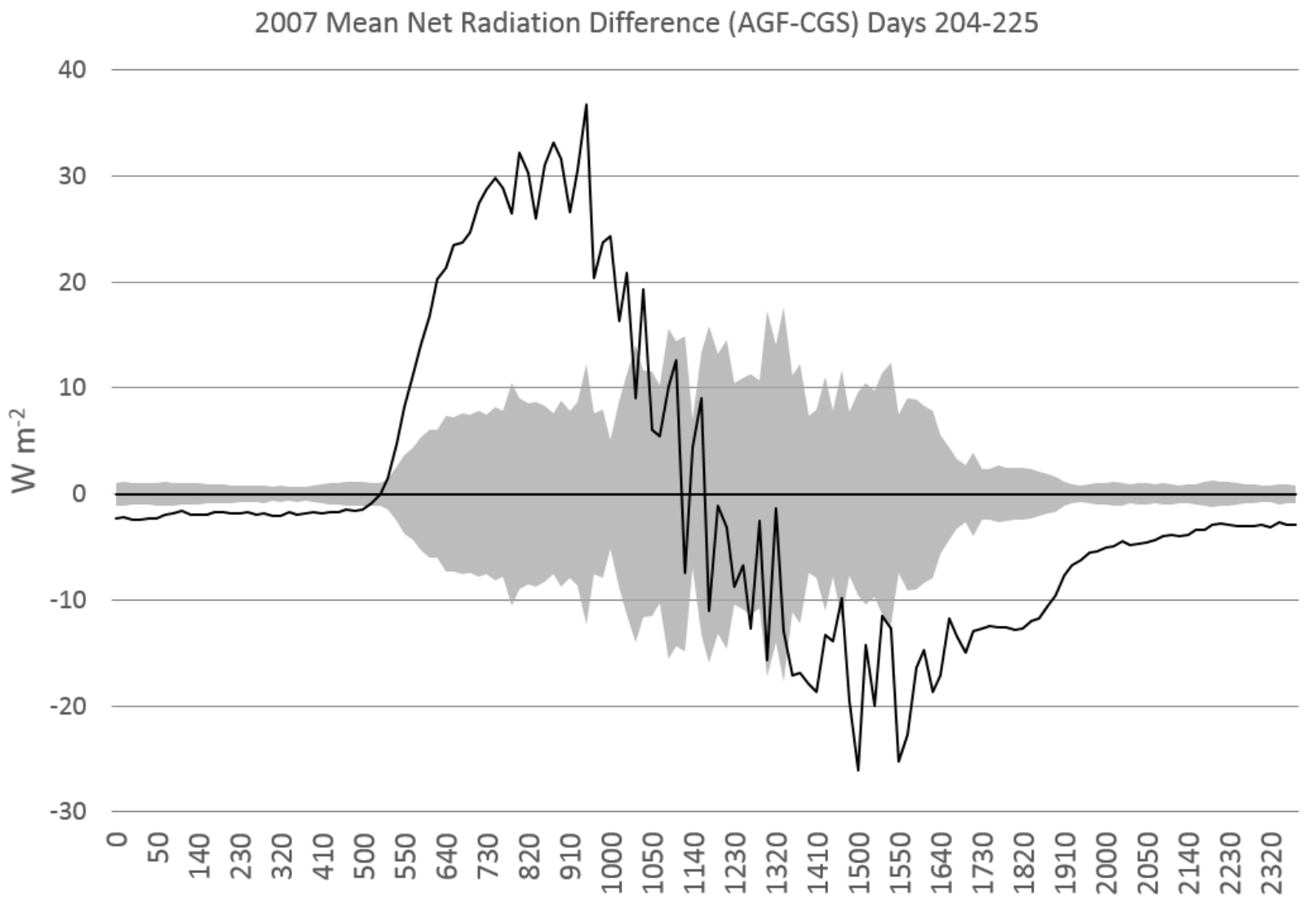

Fig. 4: The mean net radiation difference (black line) between the agroforestry buffer portion of the crop (AGF) and the contour grass strip buffer portion of the crop (CGS), see Fig. 1, for each 10-minute interval during Julian days 204-225 2007. The gray shading represents the $95 \%$ confidence interval centered on zero $\mathrm{W} \mathrm{m}^{-2}$ as determined by paired $t$ tests ( (ample sizes $=22$ ).

To further explore the potential importance of scattered radiation from both agroforestry buffers, the daily cycle of net radiation differences between the AGF site (12 $\mathrm{m}$ from the north buffer) and a site closer ( $3 \mathrm{~m}$ ) to the north buffer, AGF_2 in Fig. 1, were compared for the period 10 June - 1 July 2006. Corn was the crop in 2006 and later dates in July 2006 were excluded 
because of the expected influence of the corn height approaching the radiometer height. Note,

297 data from AGF_2 were not available for 2007, the soybean year. It is not surprising that the

298 magnitudes of the differences in net radiation between AGF and AGF_2 are small, $<6 \mathrm{~W} \mathrm{~m}^{-2}$

299 (Fig. 5), as both sites may be receiving scattered radiation from the agroforestry buffers. It is

300 very evident that differences, despite being small, had a clear diurnal cycle, and are statistically

301 significant at all times except near solar noon, and for brief periods near sunrise and sunset.

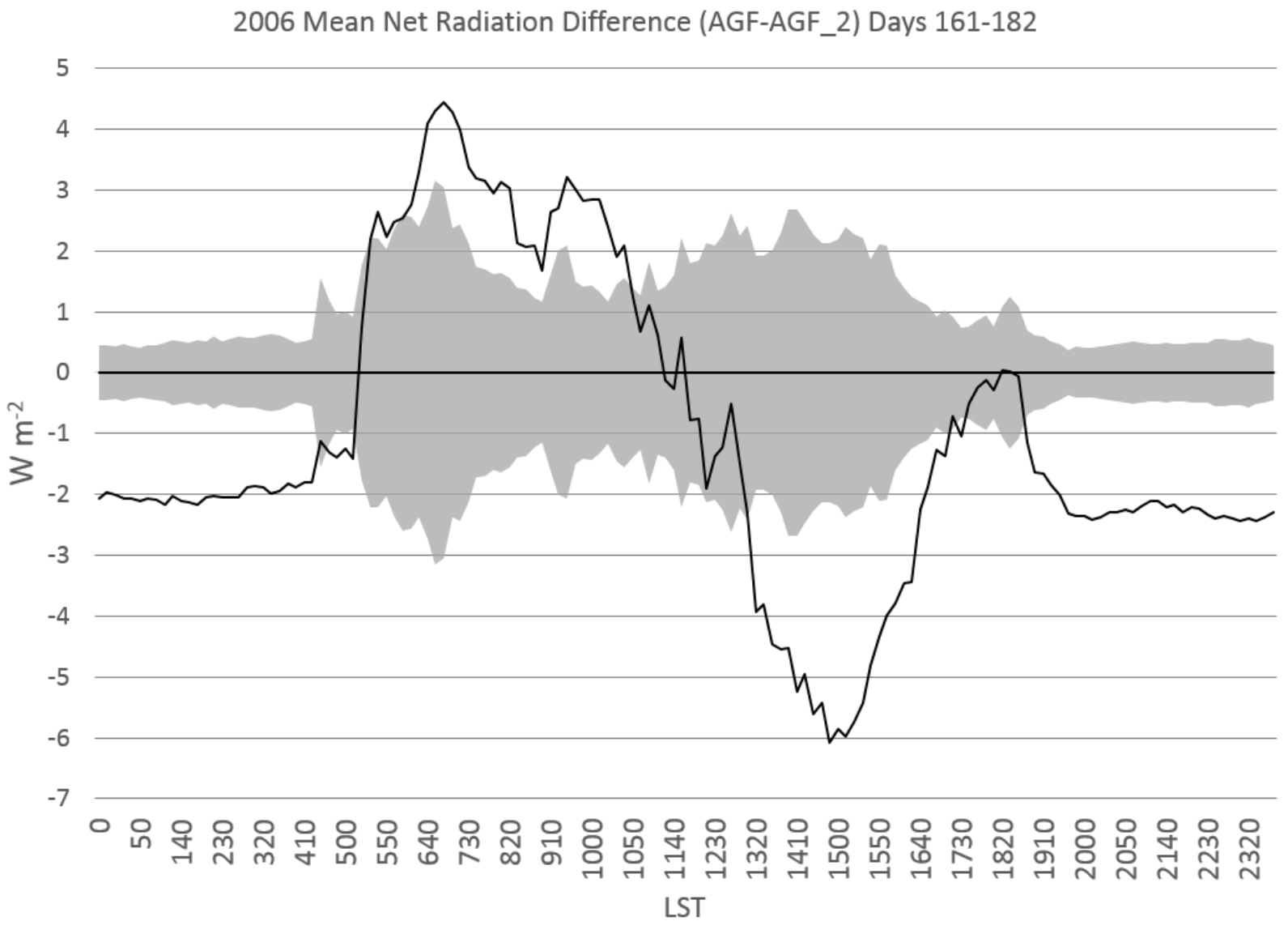

302

303

304

305

306

307

308

309

310

Fig. 5: The mean net radiation difference (black line) between the agroforestry buffer portion of the crop $12 \mathrm{~m}$ from the north agroforestry buffer (AGF) and the area $3 \mathrm{~m}$ from the north buffer (AGF_2), see Fig. 1, for each 10-minute interval during Julian days 161-182 2006. The gray shading represents the $95 \%$ confidence interval centered on zero $\mathrm{W} \mathrm{m}^{-2}$ as determined by paired $t$ tests (sample sizes $=22$ ).

At night, net radiation was greater at the site nearer to the north buffer (AGF_2), likely due to longwave radiation from the trees (Fig. 5). Soon after sunrise, however, the difference 
311 reversed, with $\mathrm{AGF}$ receiving nearly $4.5 \mathrm{~W} \mathrm{~m}^{-2}$ more net radiation at $0700 \mathrm{LST}$. At this time, the

312 solar azimuth was $\sim 79^{\circ}$ with a $\sim 24^{\circ}$ solar altitude angle. One would expect more radiation to be

313 scattered from the south buffer than the north buffer at this time, and with AGF being closer to

314 the south buffer than AGF_2, it received more radiation. As the solar azimuth approached the

315 south during the late morning, the altitude angle increased with significantly greater $(p<0.05)$

316 radiation at the AGF site until 1050 LST (Fig. 5). At this time, the azimuth was approximately

$317128^{\circ}$, yet the solar altitude angle was greater than $66^{\circ}$. It is possible that the AGF site was

318 receiving a substantial contribution of scattered radiation from both buffers at this time (Fig. 1

319 and Fig. 5). With a solar azimuth of nearly $227^{\circ}$ at $1320 \mathrm{LST}$, the direct radiation was nearly

320 perpendicular to the south buffer that is oriented southeast-northwest (Fig. 1), with AGF_2

321 receiving significantly $(p<0.05)$ more radiation than AGF (Fig. 5). At this time and through the

322 late afternoon, as the solar altitude angle lowers one would expect a lesser contribution of

323 scattered radiation from the south buffer compared to the north buffer, the buffer closer to

324 AGF_2 (Fig. 1). At 1850 LST, the altitude angle was less than $8^{\circ}$, and as expected, longwave

325 radiation differences began to be prominent (Fig. 5).

326 Terrain is very gently sloping to the north-northeast in both the CGS and AGF portions of

327 the crop (Fig. 1). Therefore, differences in slope and aspect between the two areas are unlikely to

328 have contributed to the measured net radiation differences between the two sites. Another

329 possible explanation for the diurnal net radiation difference patterns seen in Figs. 3 and 4 is tilt of

330 the net radiometers. If the AGF net radiometer was tilted slightly to the east, then this could

331 explain the disparity with the CGS location. This is unlikely, given that the magnitude of the

332 differences between AGF and AGF_2 are much smaller than the difference from CGS (e.g., Figs.

3334 and 5). Similarly, the CGS net radiometer tilted slightly to the west could explain the 
334 differences from AGF displayed in Fig. 3 and 4. To explore this possibility, data in 2007 from a

335 net radiometer over the grass strip buffer itself was compared to the AGF net radiation data.

336 Although the surfaces are different (e.g., soybean vs grass), the AGF site had increased net

337 radiation during the morning hours relative to the net radiation over the grass strip buffer itself

338 (not shown) of similar magnitudes as those seen in Figs. 3 and 4. Therefore, it is unlikely that the

339 disparities in net radiation between the AGF and CGS locations were due to the net radiometer at

340 the CGS location being tilted to the west.

\section{5. CONCLUSIONS}

343 For a 54 day period in summer 2007, evapotranspiration from a soybean crop using the

344 Penman-Monteith equation was calculated using 10-min averages of meteorological

345 measurements over an agricultural watershed within the alleys of two buffer cropping systems in

346 northeastern Missouri, agroforestry buffers (AGF) and grass only buffers (CGS). The width of

347 the crop alleys were approximately ten times the height of the agroforestry buffers and wind

348 speed was consistently lower at the AGF site, especially when winds were nearly perpendicular

349 to the buffer extents.

350 Despite the consistently lower wind speeds through the entire period, calculated

351 evapotranspiration was nearly equal at both locations for water-stressed conditions (represented

352 by a bulk surface resistance of $100 \mathrm{~s} \mathrm{~m}^{-1}$ ). From 21 June to $15 \mathrm{July}, \sim 1.7 \mathrm{~mm}$ more

353 evapotranspiration was calculated at the AGF site compared to the CGS site for water-stressed

354 conditions. This coincided with about $\sim 16,767 \mathrm{~kJ} \mathrm{~m}^{-2}$ more net radiation at the AGF site. The

355 difference in net radiation between the two sites became negligible approaching the end of the

356 summer period, 13 August 2007, and total evapotranspiration at the CGS site from 15 July to 13 
August exceeded the AGF site by $2.1 \mathrm{~mm}$ for water-stressed conditions and $6.45 \mathrm{~mm}$ for well-

358 watered conditions (represented by a bulk surface resistance of $40 \mathrm{~s} \mathrm{~m}^{-1}$ ).

359 There was a clear daily cycle in the net radiation difference between the two sites, with

360 greater net radiation at the AGF site in the morning $\left(\sim 40 \mathrm{~W} \mathrm{~m}^{-2}\right)$ and less in the afternoon. The

361 agroforestry buffers extend east-west to the east of the AGF monitoring site, and southeast-

362 northwest to the west of the site. Therefore, it is likely that easterly solar azimuths resulted in

363 additional scattered radiation from the two adjacent agroforestry buffers.

364 In short, for total calculated evapotranspiration over the 54 day period, the average 0.42

$365 \mathrm{~m} \mathrm{~s}^{-1}$ reduction in wind speed observed in the crop area surrounded by the agroforestry buffer

366 was overcome by scattered radiation from the trees for water-stressed conditions. This result may

367 be unique to humid climates due to the small vapor pressure deficits. Daytime winds were

368 observed to be $\geq 0.6 \mathrm{~m} \mathrm{~s}^{-1}$ greater over the grass buffer portion of the crop when winds were

369 nearly perpendicular to the buffers. Therefore, the orientation of agroforestry buffers relative to

370 the prevailing wind appears to be important in reducing evapotranspiration. While widening crop

371 alleys may decrease the percentage of the crop receiving scattered radiation from trees, it may

372 increase the portion of the crop outside of the wind-sheltered zones extending downwind from

373 the agroforestry buffers. Future investigations should focus on the sensitivity of net radiation and

374 wind speed to buffer orientations and crop alley width.

376 ACKNOWLEDGEMENT

This work was funded through the University of Missouri Center for Agroforestry under

379 cooperative agreements 58-6227-1-004 with the USDA-ARS and partially funded by Missouri 
381 Foundation under award 1355406, The Missouri Transect: Climate, Plants, and Community.

382 Any opinions, findings, conclusions or recommendations expressed in this publication are those

383 of the authors and do not necessarily reflect the view of the U.S. Department of Agriculture and

384 National Science Foundation.

LITERATURE CITED

Acock, M.C., Pachepsky, Ya.A., 2000. Estimating missing weather data for agricultural simulations using group method of data handling. J. Appl. Meteorol. 39, 1176-1184.

Allen, R. G., Pereira, L. S., Raes, D., Smith, M., 1998. Crop Evapotranpiration: Guildlines for computing crop water requirements, FAO Irrigation and Drainage Paper No 56. Food and Agriculture Organisation, Land and Water. Rome, Italy

Baldocchi, D.A., Verma, S.B., Rosenburg, N.J. 1985. Water use efficiency in a soybean field: influence of plant water stress. Ag. For. Met. 34, 53-65.

Baldocchi, D.A., Hicks, B.B., Camara, P. 1987. A canopy stomatal resistance model for gaseous deposition to vegetated surfaces. Atmo. Env. 21, 91-101.

400

401 Brandle, J.R., Hodges, L., Zhou. X.H., 2004. Windbreaks in North American agricultural 402 systems. Agrofor. Syst. 61, 65-78. 
404 Campi, P., Palumbo, A.D., Mastrorilli, M., 2009. Effects of tree windbreak on microclimate and wheat productivity in a Mediterranean environment. Eur. J. Agron. 30, 220-227.

407 Chendev, Y.G., Sauer, T.J., Ramirez, G.H., Burras, C.L., 2015. History of East European Chernozem soil degradation; protection and restoration by tree windbreaks in the Russian Steppe. Sustainability. 7, 705-724

Cleugh, H.A., 1998. Effects of windbreaks on airflow, microclimates and crop yields. Agroforest. Syst. 41, 55-84. Australian national windbreak program: overview and summary of results. Aust. J. Exp. Ag. 42, 649-664.

Huth, N.I., Carberry, P.S., Poulton, P.L., Brennan, L.E., Kearing, B.A., 2002. A framework for simulating agroforestry options for the low rainfall areas of Australia using APSIM. European J. Agronomy. 18, 171-185.

425 
426 Kumar, S., Anderson, S.H., Bricknell, L.G., Udawatta, R.P., 2008. Soil hydraulic properties

427 influenced by agroforestry and grass buffers for grazed pasture systems. J. Soil and Water

428 Conserv. 63, 224-232.

429

430 Kumar, S., Udawatta, R.P., Anderson, S.H., 2011. Root length density and carbon content 431 influenced by agroforestry and grass buffers under grazed pasture systems in a Hapludalf.

$432 \quad$ Agroforest. Syst. 80, 85-96.

433

434 Kuusk, A., Kuusk, J., Lang, M., 2014. Modeling directional forest reflectance with the hybrid type forest reflectance model FRT. Remote Sensing of Environment. 149, 196-204

437 Lopez-Bravo, D.F., Virginio, E.D., Avelino, J., 2012. Shade is conducive to coffee rust as compared to full sun exposure under standardized fruit load conditions. Crop Prot. 21-29.

Ortega-Farias, S., Olioso, A., Antonioletti, R., and Brisson, N., 2004. Evaluation of the Penman-

443 Quinkenstein, A., Wollecke, J., Bohm, C., Grunewald, H., Freese, D., Schneider, B.U., Huttl, 444 R.F., 2009. Ecological benefits of the alley cropping agroforestry system in sensitive regions of Europe. Environmental Sci. and Pol. 12. 1112-1121. 
447 Senaviratne, G.M.M.M.A., Udawatta, R.P., Nelson, K.A., Shannon, K., Jose, S., 2012. Temporal 448 and spatial influence of perennial upland buffers on corn and soybean yields. Agron. J. $449 \quad 104,1356-1362$.

451 Seobi, T., Anderson, S.H., Udawatta, R.P., Gantzer, C.J., 2005. Influence of grass and agroforestry buffer strips on soil hydraulic properties for an Albaqualf. Soil Sci. Soc. Am. J. 69, 893-901.

Udawatta, R.P., Krstansky, J.J., Henderson, G.S., Garrett, H.E., 2002. Agroforestry practices,

462 Udawatta, R.P., Anderson, S.H., Gantzer, C.J., Garrett, H.E., 2006. Agroforestry and grass runoff, and nutrient loss: a paired watershed comparison. J. Environ. Qual. 31, 1214-1225.

465

Udawatta, R.P., Garrett, H.E., Kallenbach, R.L. 2011. Agroforestry buffers for non point source pollution reductions from agricultural watersheds. J. Environ. Qual. 40, 800-806. buffer influence on macropore characteristics: a computed tomography analysis. Soil. Sci. Soc. Am. J. 70, 1763-1773. 

alley cropping agroforestry system in temperate North America, Comm. Soil Sci. and Plant Analysis, 00, 1-13.

472

473 Udawatta, R.P., Jose, S., 2012. Agroforestry strategies to sequester carbon in temperate North America. Agroforest. Syst. 86, 225-242.

475 